УДК 343.9

DOI https://doi.org/10.32849/2663-5313/2021.6.29

\title{
Едуард Расюк,
}

канд. юрид. наук, дочент,

професор кафедри кримінології та кримінально-виконавчого права

Начіональної академії внутрішніх справ

\section{Станіслав Мозоль,}

докт. юрид. наук, стариий науковий співробітник,

дочент кафедри кримінологї та кримінально-виконавчого права

Національної академії внутрішніх справ

\section{ПРОСТОРОВИЙ АНАЛІЗ ЗЛОЧИННОСТІ ЯК ОСНОВА ЕФЕКТИВНОГО ЗАПОБІГАННЯ ЗЛОЧИННОСТІ В УКРАЇНІ}

У статті досліджено теоретичні питання формування якісного системного аналізу злочинності й сучасної системи запобігання їи. Доведено, що саме просторовий аналіз злочинності повинен бути невід'ємною частиною комплексного дослідження злочинності в державі, а його сучасні методи дають змогу поглиблено й усебічно вивчити злочинність, використовуючи той факт, що кримінальне правопорушення має географічну характеристику - «місие скоєння злочину». Саме географічні характеристики об'єктів дослідження з картографічними даними дають можливість просторового аналізу, тобто візуалізації інформації через відображення ї̈ на модельних зображеннях територій, послуговуючись сучасними геоінформаиійними системами. Такий підхід до просторового складника злочинності на моделях зображення території дає можливість проводити класифікацію кримінальних правопорушень за географічними параметрами, виділення груп, які володіють однаковими характеристиками, пошук взаємообумовлених і причинних зв'язків тощо. Звідси й неефективність діяльності всіх суб'єктів запобіжного складника в державі щодо злочинності. У змісті статті зазначено, що «місие скоєння злочину» має конкретну адресу або географічну точку координат з характеристиками широти й довготи, дає змогу візуально відобразити та пов'язати кримінальне правопорушення з характеристиками й особливостями території, на якій воно вчинене, а вивчення типових місиь скоєння та иілих територій (системи скоєння) дає можливість виявити передумови вчинення й розробити заходи запобігання злочинності загалом чи ї̈ окремих видів. Розкрито декілька варіантів, способів і підходів просторового аналізу злочинності із зазначенням позитиву й недоліків кожного, а також зазначено, що використання карт для аналізу злочинності, зокрема просторового, дає змогу виявити географічні особливості місцевості, які впливають на рівень, структуру, характер, динаміку, иіну злочинності, формують ї̈ детермінанти, а також вчасно прийняти управлінські рішення з розробки й реалізаиї̈ ефективних заходів із запобігання та протидії кримінальним правопорушенням.

Ключові слова: злочинність, запобігання злочинності, інформаційні технології, просторова інтерпретація кримінальних правопорушень, кількісні та якісні показники злочинності, геоінформаційні системи, просторова складова злочинності.

Постановка проблеми. 3 часів незалежності України завжди гостро стояло питання щодо зниження рівня злочинності та створення дієвої системи запобігання їй, але й до сьогодні ця проблема невирішена й потребує розв'язання. Особливо гостро стоїть питання суспільства до держави щодо ефективного запобігання злочинності саме сьогодні, це викликано анексованими територіями i, як наслідок, внутрішньою міграцією та урбанізацією; тривалою операцією об'єднаних сил на сході країни й постійною загрозою повномасштабного вторгнення північного сусіда; відсутністю повного контролю за державним кордоном i, як наслідок, діяльність диверсійних груп i кримінального контингенту всередині країни; збільшенням фактичної злочинності, особливо транснаціональної організованої; неефективною діяльністю правоохоронних органів у профілактиці правопорушень i неспроможністю захистити суспільство від злочинності. В Україні діє ціла низка державних структур, яким надано право кримінального переслідування осіб, які вчинили кримінальні проступки або злочини, а також ці структури мали б прагнути запобігати кримінальним правопорушенням і створити дієву систему запобігання злочинності 
в державі. Сучасний світ технологій зі своїми розвиненими системами відеоспостереження дає змогу правоохоронним органам швидко розкривати кримінальні правопорушення й установлювати осіб, які їх учинили, а криміналістичні методи дають можливість притягнути кримінальних правопорушників до відповідальності, навіть якщо відеоспостереження відсутнє. Одначе ефективність діяльності правоохоронних органів не має оцінюватися лише кількістю виявлених, розкритих кримінальних правопорушень і притягнення до відповідальності винних осіб, а основним показником роботи має бути профілактика кримінальних правопорушень. У зарубіжних країнах (США, Великобританія) завдяки розвитку інформаційних технологій уже існує кілька експериментальних систем, що дають змогу прогнозувати спалахи кількості кримінальних правопорушень у тому чи іншому районі міста й на основі глибокого аналізу прийняти правильні управлінські рішення щодо недопущення іх учинення. У силу об'єктивних причин Україна відстає від провідних країн світу у створенні ефективної системи запобігання злочинності, але прагне до міжнародних стандартів безпеки. Прикладом цього слугують системи «Безпечне місто» та інтеграція приватних відеокамер спостереження до неї, що дає змогу вчасно приймати управлінські рішення й заздалегідь направити додаткові патрулі.

Немає й узгоджених теоретичних уявлень про аналіз показників злочинності та запобігання їй в Україні. Цей аспект тим чи іншим чином висвітлювався практично всіма відомими вітчизняними кримінологами, зокрема А. Бабенко, В. Батиргареєвою, А. Бойком, О. Бугерою, В. Глушковим, Б. Головкіним, Л. Давиденком, I. Даньшиним, О. Джужою, В. Дрьоміним, А. Закалюком, А. Зелінським, О. Кальманом, О. Костенком, О. Колбом, I. Лановенком, О. Литвиновим, О. Манжай, Є. Орловим, В. Поповичем, В. Пересадько, Б. Розовським, В. Струковим, Д. Узловим, О. Храмцовим, В. Шакуном, О. Шостко та ін. Кожний із дослідників пропонує власне бачення цієї проблеми та оперує відповідною термінологією. На наше глибоке переконання, узгоджене уявлення сутності й змісту просторового аналізу злочинності вдасться напрацювати в межах консолідованої теорії запобігання злочинності, основи якого сьогодні лише починають формуватися.

Головною метою статті є 3'ясування суті просторового аналізу злочинності відповідно до авторського бачення й обгрунтування необхідності його обчислення при аналізі злочинності для ефективного запобігання їй.
Виклад основного матеріалу. Аналіз стану й тенденцій кримінальних правопорушень у розрізі просторової інтерпретації даних $є$ запорукою успіху формування ефективної державної системи запобігання та протидії злочинності. Вивчаючи злочинність як соціально-правове, відносно масове, історично-мінливе та самодетермінуюче явище, яке складається із сукупності скоєних кримінальних правопорушень та осіб, які їх учинили, на певній території за певний проміжок часу, ми можемо застосовувати методи просторового аналізу для поглибленого й усебічного вивчення цього явища, використовуючи той факт, що кримінальне правопорушення має географічну характеристику - «місце скоєння». Сьогодні кримінологічною наукою вже розроблена низка кількісних і якісних показників, за допомогою яких злочинність може бути обрахована, виміряна або обчислена, що значно полегшує практикам здійснювати роботу з боротьби 3 нею. Такими показниками є рівень (коефіцієнти інтенсивності, злочинної активності, судимості, віктимності), динаміка, ціна, структура, характер, географія злочинності [3, c. 48]. В останні десятиліття стрімкий розвиток отримали геоінформаційні системи сучасні комп'ютерні рішення, які дають можливість відображати модельні зображення території у вигляді карт чи аерофотознімків або, у їх більш сучасному варіанті, фотозображення земної поверхні, отримані із супутників, і працювати з ними.

Виділення географічних характеристик об'єктів дослідження 3 картографічними даними дає можливість просторового аналізу, тобто візуалізація частини інформації через відображення географічного складника на модельних зображеннях територій - це один із інструментів аналізу даних, які до цього були у вигляді текстів, таблиць, графіків тощо. Відображення просторового складника злочинності на моделях зображення території дає можливість проводити класифікацію кримінальних правопорушень за географічними параметрами, виділення груп, які володіють однаковими характеристиками, і пошук взаємообумовлених i причинних зв'язків. «Місце злочину» як конкретна адреса або географічна точка координат з характеристиками широти та довготи дає змогу візуально відобразити та пов'язати кримінальне правопорушення з характеристиками й особливостями теритоpiï, на якій воно вчинене. Вивчення типових місць скоєння та цілих територій (системи скоєння) дає можливість виявити передумови вчинення. Відсутність поряд людних місць, наявність закинутих приміщень чи 
звалищ, велика відстань до місць проживання людей, можливість швидко покинути місце злочину - усі ці особливості місцевості можуть спонукати злочинця до скоєння суспільно небезпечного діяння. Географічні особливості місця конкретного кримінального правопорушення, територіальні особливості різних їх груп дають можливість більш детального вивчення їх чинників і розробку заходів запобігання злочинності загалом чи її окремих видів.

Найбільш простим варіантом просторового аналізу злочинності є відображення їі на модельному зображенні території. Найбільш зручним інструментом тут $є$ карти, які дають можливість чітко відобразити географію злочинності (рис. 1). Використання фотозображень земної поверхні $€$ менш зручним i вивченим сьогодні, а робота 3 ними є більш складною та потребує володіння додатковими знаннями. Роботу 3 геоінформаційними системами можна організувати 3 використанням технологій і можливостей усесвітньої глобальної мережі Інтернет, наприклад, Google Maps (http://maps.google.com), Яндекс.Карти (http://maps.yandex.ua), OpenStreetMap (http://www.openstreetmap.org), Wikimapia (http://wikimapia.org) тощо.
Сучасні геоінформаційні системи дають змогу оперувати загальноприйнятими суспільними географічними назвами (місто, вулиця, номер будинку) і суто географічними координатами (широта та довгота), це дає можливість відображати місце скоєння кримінального правопорушення як через конкретний адрес (наприклад: місто Київ, вулиця Миколи Закревського, 63А), так і через положення мітки місця кримінального проступку чи злочину на карті (рис. 1, мітка № 5), яка має тільки географічну широту та довготу. Користувацький інтерфейс сучасних систем дає можливості розміщувати мітки через адресу, широту та довготу або простим візуальним розміщенням її на карті. Просте візуальне розміщення на карті мітки (указати курсором миші на карті місце) є доцільним у випадках, коли відсутня чітка адреса місця скоєння кримінального правопорушення. У таких випадках ми зазвичай маємо тільки словесний опис місцевості (метрів 30 за будинком № 30 по вулиці Миколи Закревського біля озера» (рис. 2, мітка № 7).

Сучасні геоінформаційні системи дають можливості знайти географічне місце, наприклад, коли немає чіткої адреси, а лише усний опис учасника події (свідка, потерпілого). У такому випадку, включа-

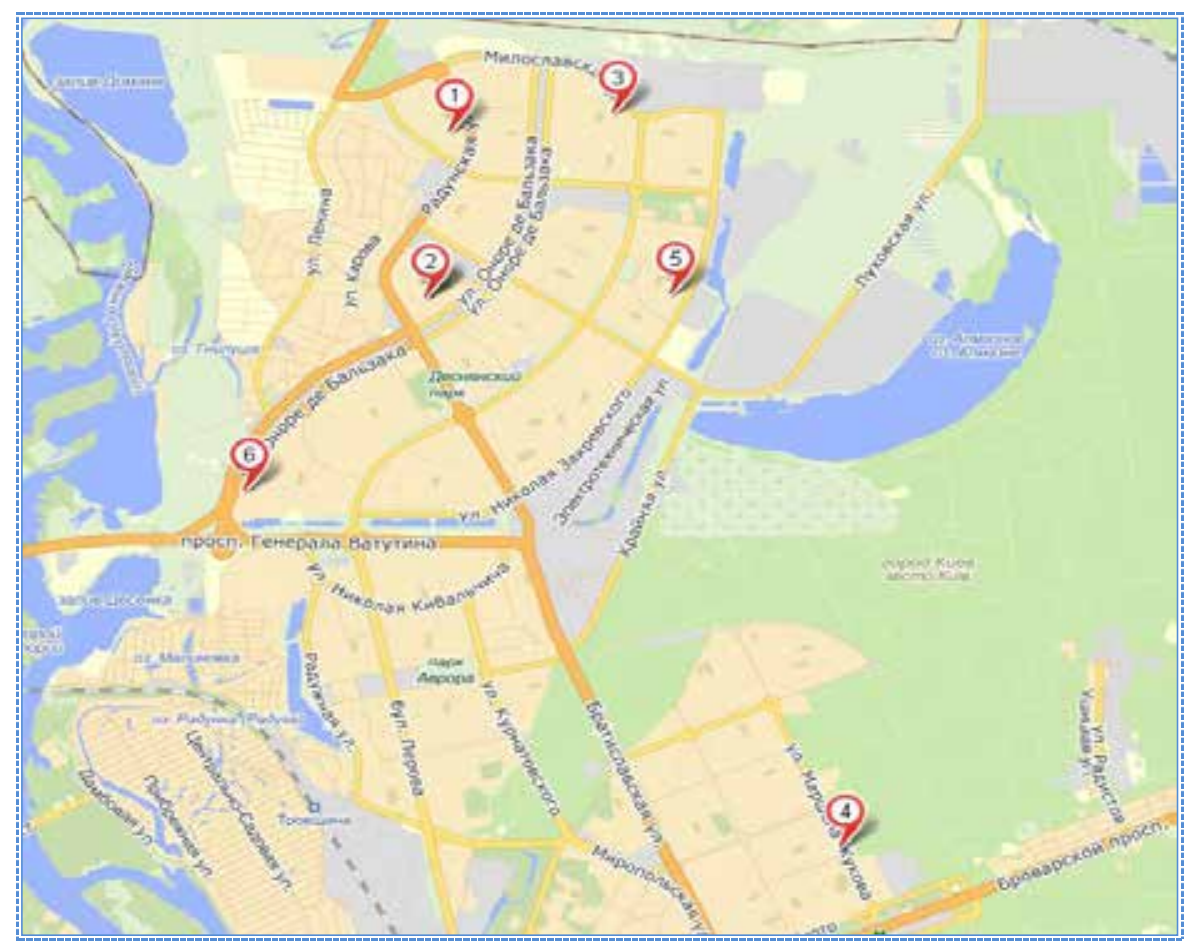

Рис. 1. Відображення місць учинення кримінальних правопорушень на карті міста Києва (Деснянський район) 


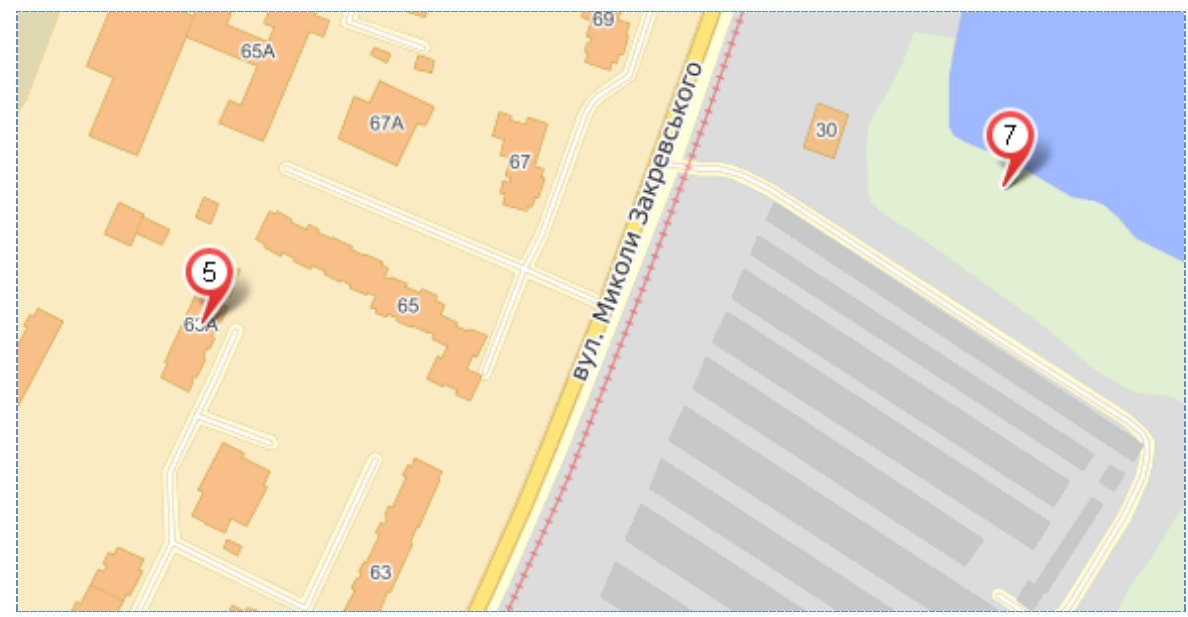

Рис. 2. Відображення на карті місця скоєння кримінального правопорушення з чіткою адресою і розташуванням на території міста Києва (Деснянський район)

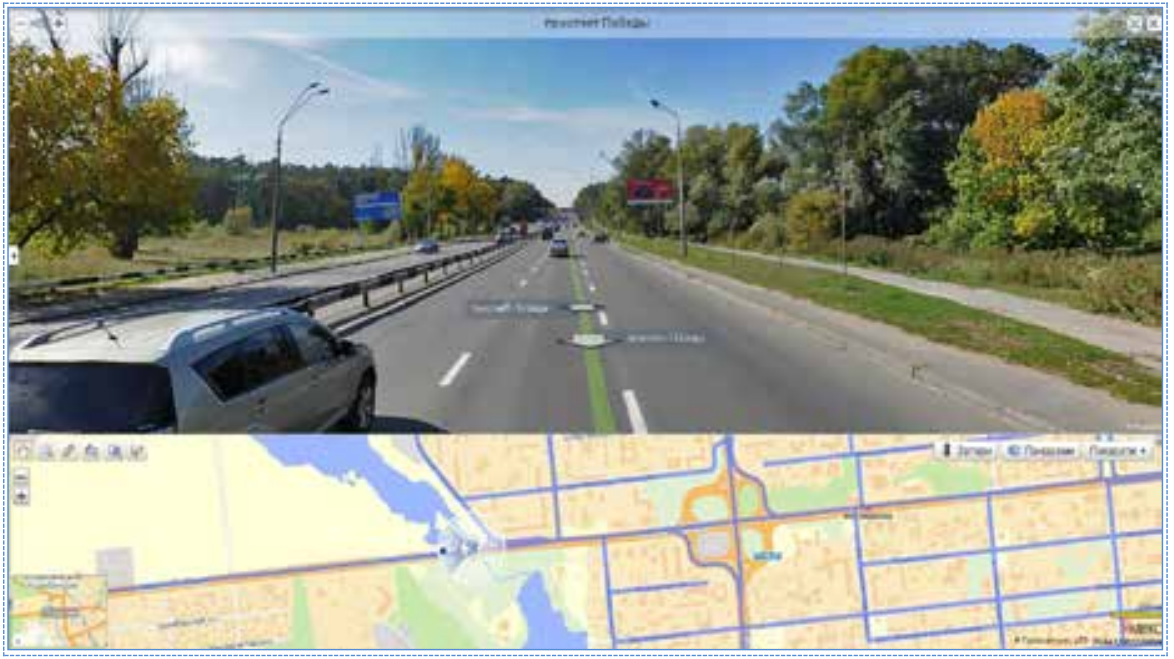

Рис. 3. Орієнтація на карті через панорамний перегляд у ГІС місцевості (місто Київ Святошинський район)

ючи режим візуального перегляду (Google Maps - «Перегляд вулиць», Яндекс.Карти «Панорами») та використовуючи елементи керування - «вперед», «назад», «ліворуч», «праворуч», знаходимо потрібне місце (наприклад, назви вулиці та вивіски, яка розміщувалася на малій архітектурній формі (МАФ), торговій палатці, тощо) (рис. 3).

Після відображення місць скоєння кримінальних правопорушень на карті (рис. 4) найпростішим варіантом аналізу є оцінка локальних територій, на якій збільшена кількість міток порівняно з іншими територіями.

При визначенні територіальних зон концентрації злочинності можна використовувати один із двох таких підходів:
- перший - із прив'язкою до адміністративно-територіальних одиниць, наприклад, для міста Києва можуть виступати міські райони - Деснянський, Дніпровський, Печерський, Солом'янський тощо. У такому випадку ми говоримо, що в наявності збільшена/найбільша концентрація злочинності в тому чи іншому районі (див. рис. 5). Цей підхід показує найбільшу концентрацію скоєних кримінальних правопорушень, проводиться й без використання карт і широко використовується в роботі штабів Національної поліції. При фіксуванні інформації про кримінальне правопорушення та peaгуванні на нього використовується територіальна структура побудови органів і під- 


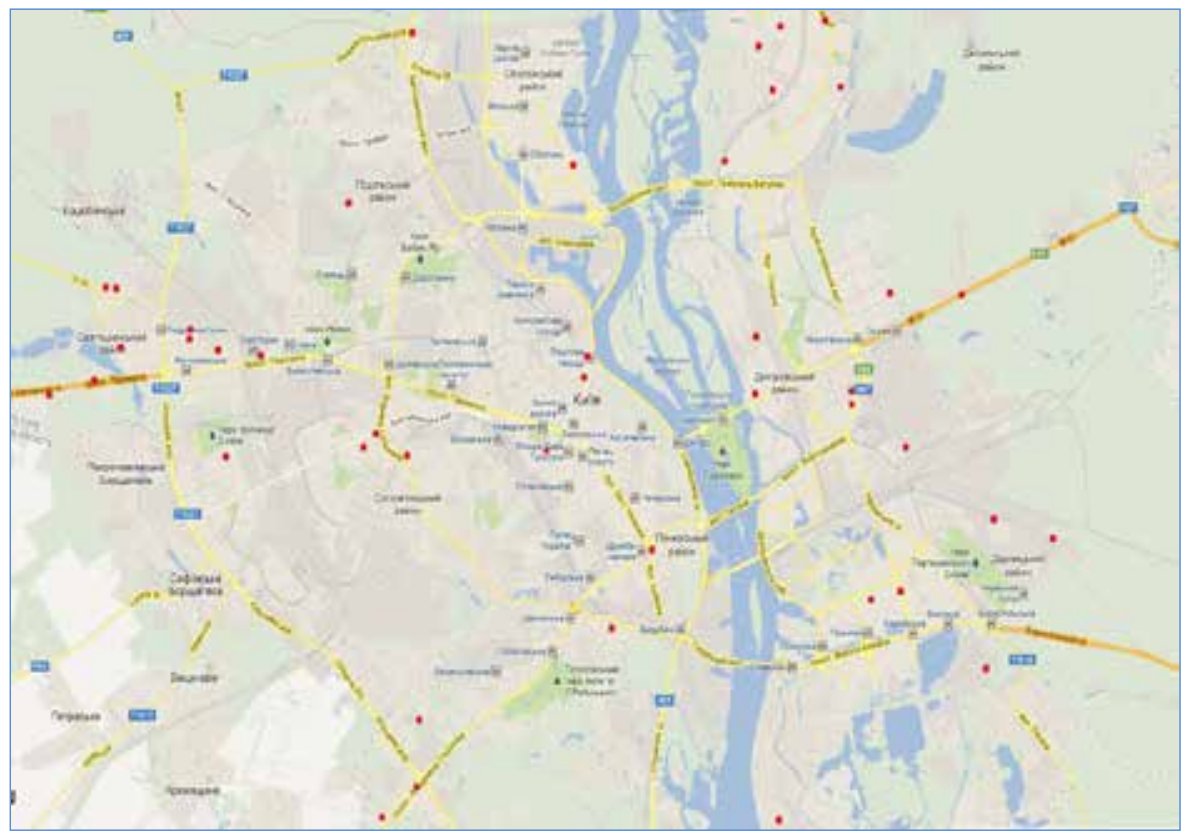

Рис. 4. Відображення географії злочинності Києва

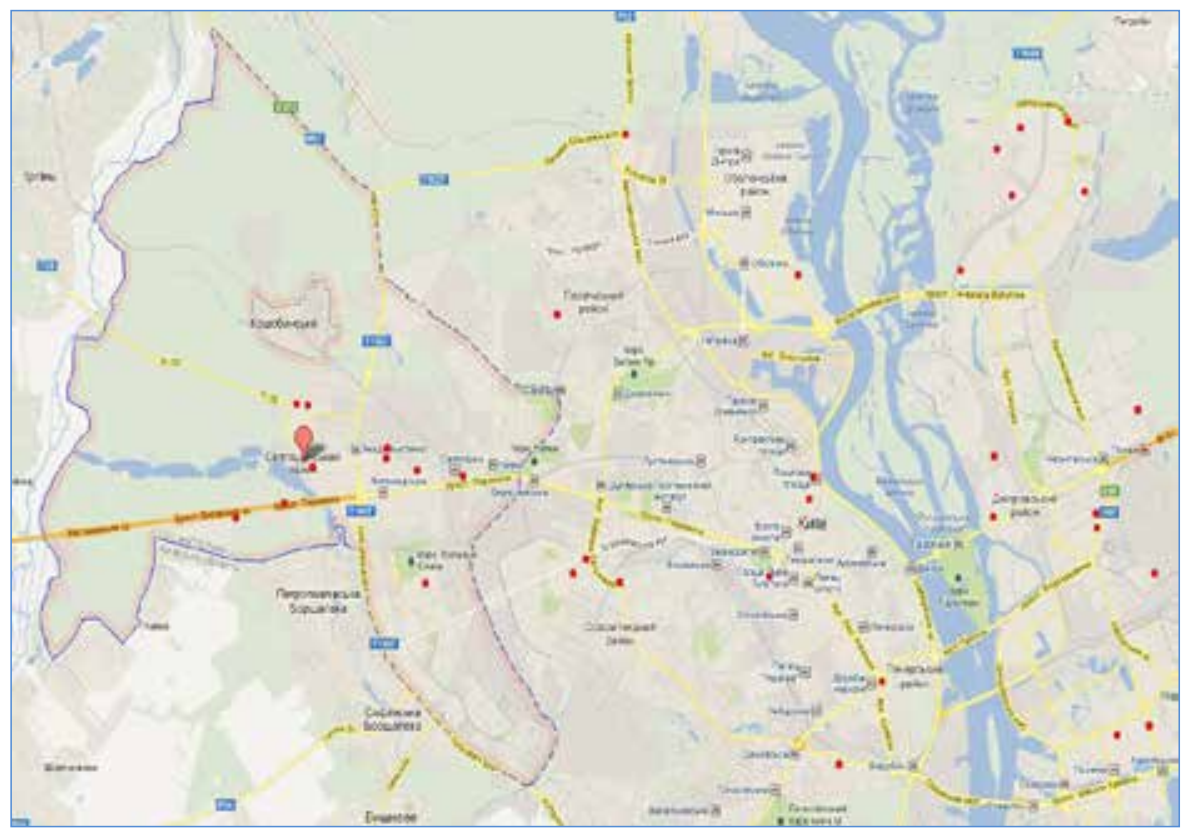

Рис. 5. Відображення меж Святошинського району міста Києва

розділів Національної поліції, тобто зразу визначається адміністративно-територіальна одиниця, на території якої відбулася подія, і передається у відповідний підрозділ Національної поліції. У подальшому при узагальненні інформації про скоєні кримінальні правопорушення отримуються відомості, у яких показники відображаються 3 прив'язкою до відповідних адміністративно-територіальних одиниць. Цей підхід є простим, але ефективним при лінійному розподілі території на області й закріплення за ними відповідальних структурних підрозділів Національної поліції; 
- другий - із прив'язкою до зон із підвищеним показником рівня злочинності, який, на відміну від першого підходу, не прив'язується до адміністративно-територіальних одиниць, а виділяє територіальні зони з високими показниками злочинності на їх територій (див. рис. 6).

Зони 3 № 2, 3, 4, 5 мають поодинокі випадки скоєння кримінальних правопорушень на їх територій, натомість зони № 1 і 6 мають на своїй території збільшену кількість злочинів і є зонами активності. Окрім коефіцієнта інтенсивності злочинності, для порівняння між собою та визначення територіальних зон активності варто розраховувати коефіцієнти, які б відображали просторову характеристику злочинності, а саме: 1) співвідношення загальної кількості кримінальних правопорушень на певній території за певний проміжок часу та загальної площі всієї території, який характеризував би ступінь поширення (охоплення території) злочинності; 2) співвідношення загальної кількості кримінальних правопорушень на певній території за певний проміжок часу та забудованої (заселеної) площі всієї території, який характеризував би ступінь поширення (охоплення території) злочинності на забудованій (заселеній) території.

Створення простих точкових мап (pin mapping), де точки відображають кримінальне правопорушення та розміщуються на мапі за відповідними координатами, є най- більш простою технікою. Основними недоліком застосування такої техніки в межах відображення кримінальних подій є те, що в разі великої кількості правопорушень на невеликому осередку місцевості або повторюваності певних подій їх буде вкрай складно відобразити на карті. Це може викликати ускладнення з розумінням поточної ситуації на території обслуговування [5, с. 67]. Тому такі способи ефективні лише для окремих видів злочинності (кібернетична, організована, тощо) або кримінальних правопорушень (убивства, розбої, згвалтування тощо), генеральна сукупність яких не $є$ великою, і невеликих територій (окремого району невеликого міста, районного центру, об'єднаної територіальної громади).

Удосконалити точкову (координатну) систему та додати ефективності просторовому аналізу злочинності допоможе розрахунок ступеня активності злочинності через механізм тепло карт (у зарубіжній літературі він має назви «heat map» або «hotspots»). Для застосування теплових карт закладається принцип: чим більша кількість об'єктів містить певна область на карті, тим яскравішим кольором вона зафарбовується. Зазвичай для виділення вибирають градацію кольорів від спокійних до дуже яскравих, наприклад, найбільш активні мікрорайони міста Києва будуть зафарбовуватися червоним кольором, що буде відображати найбільшу ступінь активності (сконцентрованість) злочинності на цій територій (рис. 7).

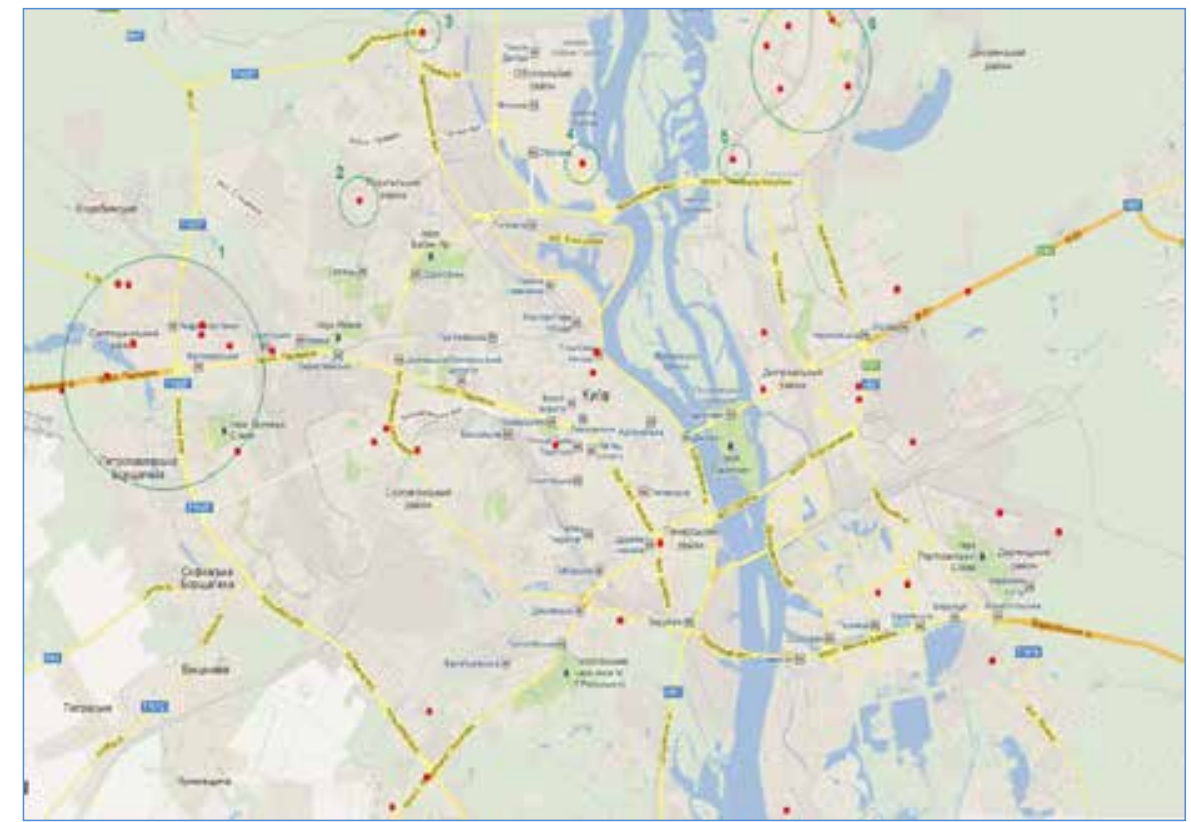

Рис. 6. Виявлення на карті місць із підвищеними показниками рівня злочинності 


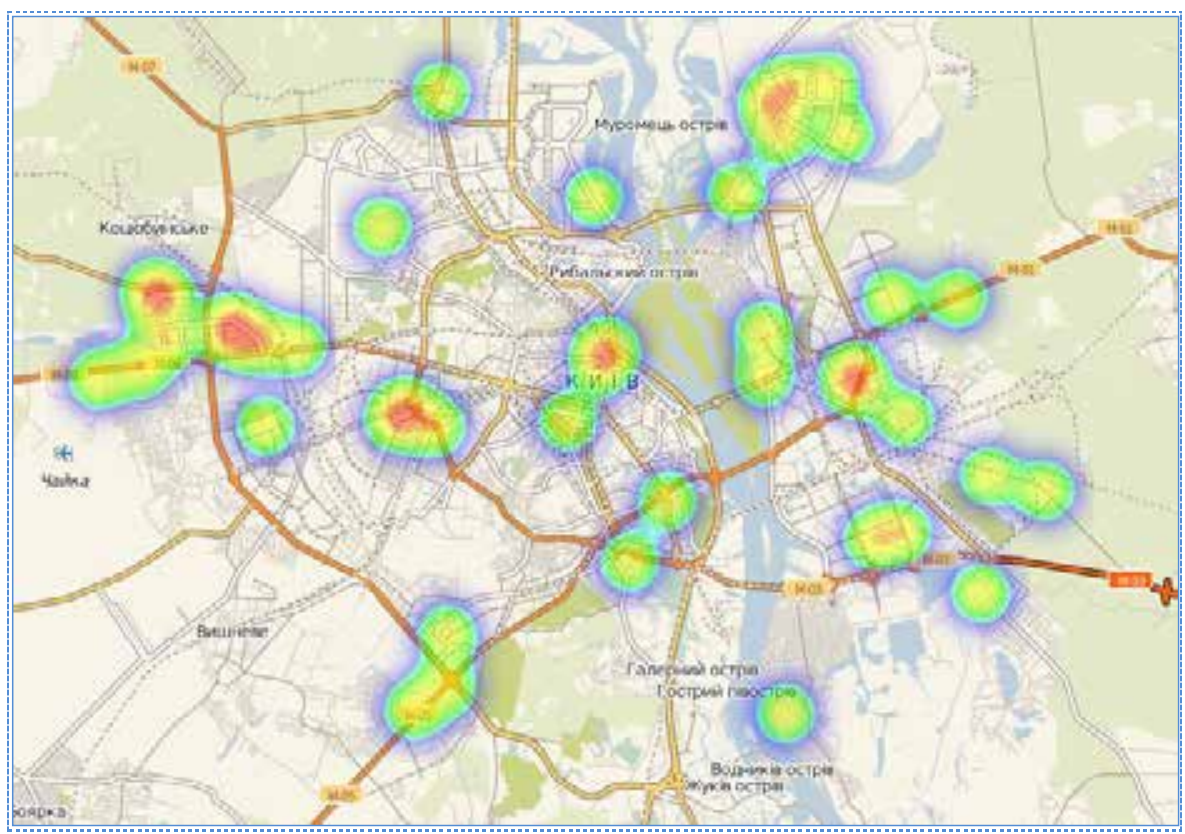

Рис. 7. Використання теплових карт для відображення рівня злочинності

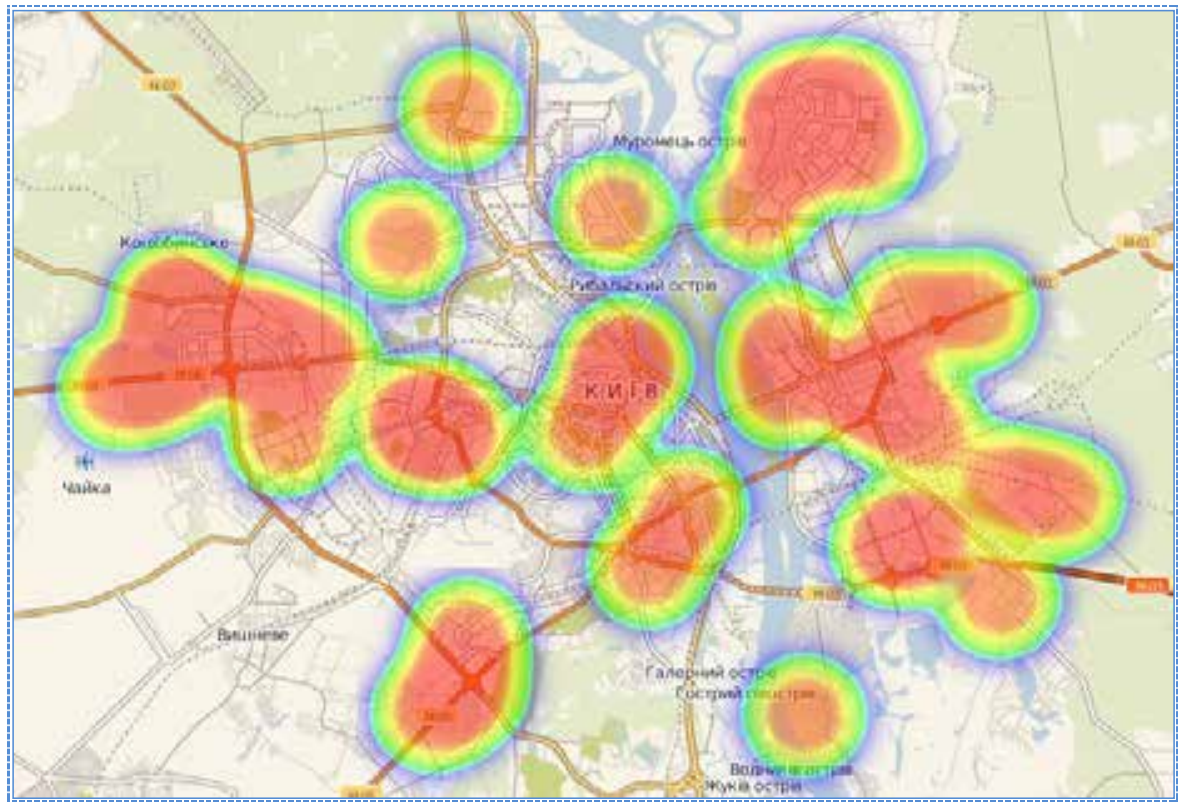

Рис. 8. Збільшення радіусу територіальних зон, що використовуються при побудові теплової карти

При ефективному використанні в роботі теплових карт варто розуміти технологію їх побудови. При обробці статистичних даних і виявленні зон активності враховуються два параметри, які суттєво впливають на кінцеве візуальне відображення:

1) радіус територіальної зони, який задається в метрах або кілометрах і фіксує величину умовного круга на карті, у межах якого підраховується кількість об' єктів, які потрапили в нього. Відповідно, якщо радіус зони буде значно великим, то міститиме більше територіальних об'єктів і вся територія зони буде зафарбовуватися в яскраві кольори (рис. 8), відображаючи підвищену активність. 


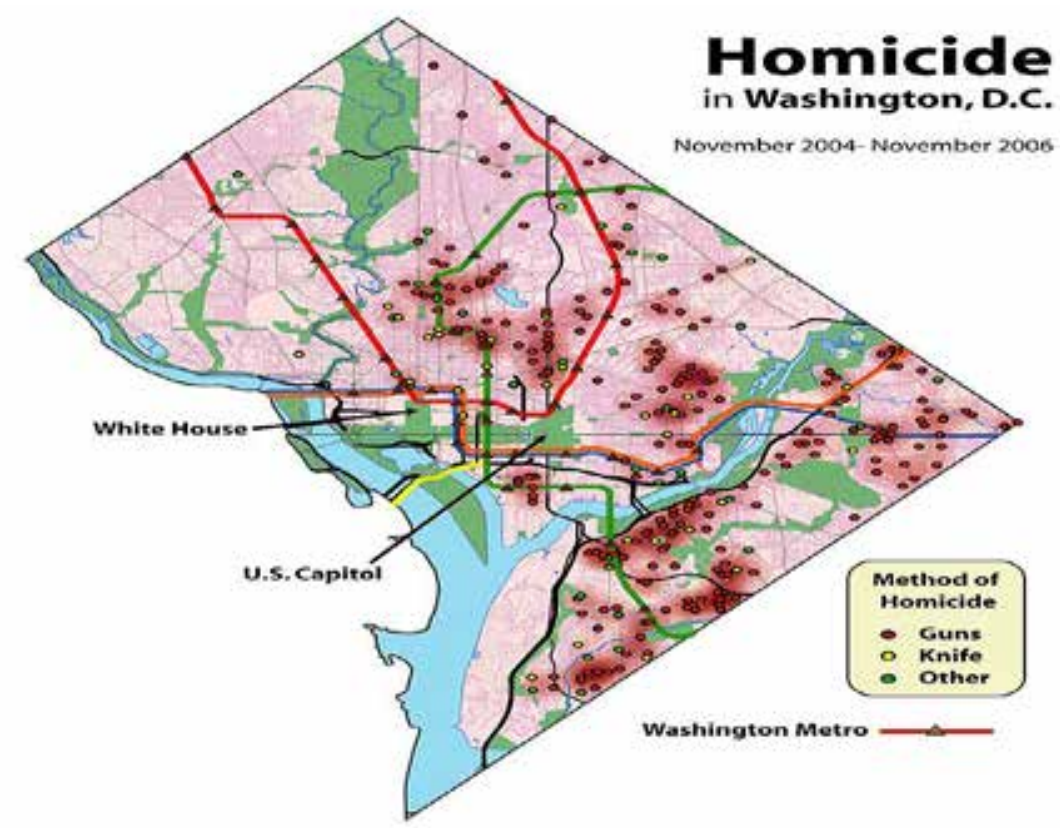

Рис. 9. Теплова кримінальна карта скоєних вбивств за листопад 2004 листопад 2006 років. Вашингтон, Округ Колумбія, США

У цьому випадку реальна картина буде спотворюватися та відображати підвищену активність на різних територіях. Різниця добре видна в порівнянні, у першому випадку радіус зони аналізу був один кілометр, то в другому випадку вже становив два кілометри, у результаті чого збільшилася територія зон і їх активність. Постає питання: «Який радіус зон найбільш доцільно вибрати?» Конкретної відповіді на це питання не має, і вона залежить передусім від загальної території, у межах якої ви проводите аналіз. У нашому випадку, коли статистичні дані знаходяться в межах міста Києва, варто вибирати найменшу територіальну зону, активність у межах якої ми досліджуємо. Якщо задати радіус десять чи двадцять кілометрів, то такі зони будуть включати практично цілі райони міста Києва та відображати на карті ї активність, а тому доцільно використовувати такий радіус у межах усієї території України, адже, узявши невеликий радіус, теплова карта не відобразить правильно зони активності. У межах цілої країни найменшою зоною активності може виступати радіус області або району. Доцільним для міста брати один кілометр як радіус середнього мікрорайону міста;

2) границі чутливості, іншими словами, це межі, які задають перехід кольорів активності при відображені їх на карті. Якщо в першому випадку (рис. 7) установлено п'ять меж переходів кольорів (від 0 до 0,45 - синій колір; від 0,45 до 0,55 - бірюзовий колір; від 0,55 до 0,65 - зелений колір; від 0,65 до 0,95 жовтий колір; від 0,95 до 1 - червоний колір), то в другому, збільшивши межі (від 0,75 до 1) для червоного кольору, що відображає найбільшу активність, на карті збільшиться кількість активних зон, а реальна картина буде спотворена, показуючи гіперактивність на території.

Описані вище крайні два параметри налаштування відображення зон активності на карті можуть суттєво змінити візуальне (кольорове) позначення територій. Неправильне налаштування їх спотворить реальну картину, та застосування теплокарт не буде ефективним.

Звичайно, описані нами способи просторового аналізу злочинності не є вичерпними й повними, скоріше, його невеликим складником, адже розвинені країни світу рухаються в ногу з новітніми інформаційними технологіями, послуговуючись ними в боротьбі зі злочинністю. Таким процесам нашій державі потрібно повчитися в Сполучених Штатів Америки $^{1}$ (рис. 9), де створення карт злочинності є ключовим компонентом поліцейської статистики і кримінального аналізу, а про-

1 Уперше спосіб комп'ютерного моделювання даних шодо злочинів з їх накладенням на карти був здійснений у Чикаго в 1986 році, коли департамент поліції виграв грант для втілення кримінальної картографії в життя, а згодом цю ініціативу перейняли інші великі міста США. 
сторовий аналіз кримінальних правопорушень $є$ основою ефективного запобігання злочинності, де картографічна візуалізація кримінальних проступків і злочинів поряд з іншими розрахунками допомагає прийняти правильні управлінські рішення в боротьбі зі злочинністю.

В Україні зарубіжний досвід просторового аналізу злочинності 3 використанням геоінформаційної системи (ГІС) поки не використовується поліцією, проте існує соціальний проект з візуалізації злочинності (zloch.in.ua), де зображено криміногенність у розрізі областей за деякими видами кримінальних правопорушень і створено «гарячу» карту злочинності по місту Києву [2]

\section{Висновки}

Отже, з огляду на викладене, доходимо висновку, що значний прорив останніми роками сучасної геоінформаційної системи (ГІС) і її доступність користувачеві є зручним інструментом для візуалізації географічних даних злочинності. Безпосередне використання карт для аналізу злочинності, зокрема просторового, дає змогу виявити географічні особливості місцевості, які впливають на рівень, структуру, характер, динаміку, ціну злочинності, формують її детермінанти, а також вчасно прийняти управлінські рішення щодо розробки й реалізації ефективних заходів із запобігання та протидії кримінальним правопорушенням. Щодо створення ефективної системи запобігання злочинності в Україні, то, по-перше, просторовий аналіз злочинності має бути частиною такої системи, адже на основі цих та інших розрахунків і їх співставлення в часі здійснюється прогнозування злочинності, що є основою планування заходів протидії їй; nо-друге, кримінологи, послуговуючись просторовим аналізом злочинності, можуть корелювати інші статистичні дані: демографічні, соціальні, економічні, архітектурні тощо, що дає змогу краще зрозуміти глибинні кореневі причини скоєння кримінальних правопорушень і допомогти державі вчасно реагувати на ці виклики; по-третє, запровадження зарубіжних провідних методик [1, с. 559] просторового аналізу злочинності й забезпечення спеціальним програмним забезпеченням регіональних органів і підрозділів Національної поліції дасть змогу вчасно реагувати на криміногенні прояви та ефективно запобігати злочинності, її окремим видам і конкретним кримінальним правопорушенням; по-четверте, налагодження процесів прогнозування злочинності й планування заходів протидії їй, основою яких є просторовий аналіз злочинності, допоможе нашій державі вибудувати ефективну кримінальну політику, де правоохоронні органи як спеціальні суб'єкти її здійснення будуть вчасно впливати (ранній етап - криміногенні детермінанти) на злочинність, а не долати шкоду, завдану внаслідок учинення кримінальних правопорушень.

\section{Список використаних джерел:}

1. The Philadelphia predictive policing experiment / J.H. Ratcliffe, R.B. Taylor, A.P. Askey et al. Journal of Experimental Criminology. 2020. № 78 (2). P. 558-567. URL: https://doi. org/10.1007/s11292-019-09400-2.

2. Кримінальна картографія. Вікіпедія вільна енциклопедія. URL: https://uk.wikipedia. org/wiki/ Кримінальна_картографія.

3. Кримінологія : підручник / Б.М. Головкін, В.В. Голіна, О.В. Лисоєд та ін. ; за ред. Б.М. Головкіна. Харків : Право, 2020. 384 с.

4. Кримінологія : підручник / О.М. Джужа, В.В. Василевич, В.В. Чернєй, С.С. Чернявський та ін. ; за заг. ред. докт. юрид. наук, проф. В.В. Чернєя ; за наук. ред. докт. юрид. наук, проф. О.М. Джужі. Київ : ФОП Маслаков, 2020.612 с.

5. Манжай О.В., Потильчак А.О. Особливості картографування злочинних проявів. Право i безпека. 2020. № 4 (79). C. 66-72. URL: https:// doi.org/10.32631/pb.2020.4.10.

Eduard Rasiuk, Stanislav Mozol. Dimensional analysis of crime as a basis of effective crime prevention in Ukraine

Theoretical issues of formation of qualitative system analysis of crime and modern system of its prevention are investigated. It is proved that the spatial analysis of crime should be an integral part of a comprehensive study of crime in the state, and its modern methods allow in-depth and comprehensive study of crime, using the fact that a criminal offense has a geographical characteristic - "crime scene". It is the geographical characteristics of the objects of study with cartographic data that allow spatial analysis, ie the visualization of information through its reflection on model images of territories, using modern geographic information systems. This approach to the spatial component of crime on the models of the image of the territory makes it possible to classify criminal offenses by geographical parameters, the selection of groups with the same characteristics, the search for interdependent and causal links, and so on. Hence the inefficiency of all subjects of the preventive component in the state in relation to crime. The content of this article states that the "crime scene" has a specific address or geographical coordinate point, with characteristics of latitude and longitude, allows you to visually display and link the criminal offense with the characteristics and features of the territory where it was committed, and the study of typical places 
commission and entire territories (systems of commission) makes it possible to identify the preconditions for the commission and to develop measures to prevent crime as a whole or its individual types. Several options, methods and approaches of spatial analysis of crime are revealed, indicating the positives and shortcomings of each, and it is noted that the use of maps for crime analysis, in particular spatial, allowes to identify geographical features that affect the level, structure, nature, dynamics, price of crime, form its determinants, as well as make timely management decisions to develop and implement effective measures to prevent and combat criminal offenses.

Key words: crime, crime prevention, information technology, spatial interpretation of criminal offenses, quantitative and qualitative indicators of crime, geographic information systems, spatial component of crime. 